\title{
Article
}

\section{The Effect of Sol-Gel Coatings on the Phosphorus (P) Adsorption Capacity of Calcareous Materials for Use in Water Treatment}

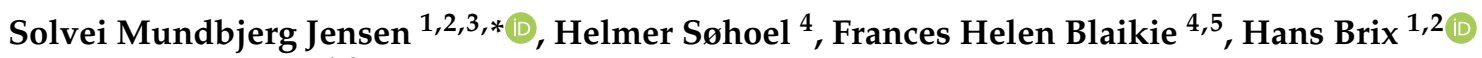 \\ and Carlos A. Arias 1,2 \\ 1 Department of Biology, Aarhus University, Ole Worms Allé 1, 8000 Aarhus, Denmark; \\ hans.brix@bio.au.dk (H.B.); carlos.arias@bio.au.dk (C.A.A.) \\ 2 Aarhus University Centre for Water Technology (WATEC), Department of Biology, Aarhus University, \\ Ny Munkegade 120, 8000 Aarhus, Denmark \\ 3 Sino-Danish Centre for Education and Research (SDC), Niels Jensens Vej 2, 8000 Aarhus, Denmark \\ 4 Coating and Polymer Technology, Danish Technological Institute (DTI), Kongsvang Allé 29, \\ 8000 Aarhus, Denmark; helmer.sohoel@gmail.com (H.S.); frances@blaikiesciencesolutions.co.nz (F.H.B.) \\ 5 Blaikie Science Solutions, Invermay AgResearch Campus, Puddle Alley 176, Mosgiel 9053, New Zealand \\ * Correspondence: solvei.mundbjerg@bio.au.dk
}

check for

updates

Citation: Jensen, S.M.; Søhoel, H.; Blaikie, F.H.; Brix, H.; Arias, C.A. The Effect of Sol-Gel Coatings on the Phosphorus (P) Adsorption Capacity of Calcareous Materials for Use in Water Treatment. Water 2022, 14, 3. https://doi.org/10.3390/w14010003

Academic Editors: Wei Ma and Gaurav Sharma

Received: 30 October 2021

Accepted: 17 December 2021

Published: 21 December 2021

Publisher's Note: MDPI stays neutral with regard to jurisdictional claims in published maps and institutional affiliations.

Copyright: (C) 2021 by the authors. Licensee MDPI, Basel, Switzerland. This article is an open access article distributed under the terms and conditions of the Creative Commons Attribution (CC BY) license (https:// creativecommons.org/licenses/by/ $4.0 /)$.

\begin{abstract}
Phosphorus (P) removal has proven difficult in decentralized wastewater treatment systems, and $\mathrm{P}$ binding material, installed as an external filter, has been proposed for improving $\mathrm{P}$ removal. Especially, calcium (Ca)-rich materials have shown promising results. (2) Five calcareous materials were tested with isotherm batch experiments. The material with the highest $\mathrm{P}$ adsorption capacity was selected to undergo different Sol-Gel coatings, i.e., different coating dilution ratios (1:10, $1: 5$, and 1:1) and exposure periods $(5,10$, and $15 \mathrm{~min})$. The seven coated materials were evaluated by isotherm experiments. (3) The maximum adsorption capacity $\left(Q_{\max }\right)$ was determined by fitting the Langmuir equation. $Q_{\max }$ for the non-coated materials, and ranged from 0.7 (sand) to 35.1 (Catsan) $\mathrm{mg} \mathrm{P} \mathrm{g}^{-1} \mathrm{DW}$, while the coated materials ranged from 7.8 to $24.7 \mathrm{mg} \mathrm{P} \mathrm{g}^{-1} \mathrm{DW}$ depending on the coating. Based on the rotated Principal Component Analysis, the most important parameters for $Q_{\max }$ were the texture and the Ca content. (4) Catsan was the most promising material, but when performing a Sol-Gel coating, a trade-off between preserving $Q_{\max }$ and the coating thickness were evident, as the materials with the thinner coating preserved more of the sorption capacity. The development of $\mathrm{P}$ binding materials constitutes a useful technology in decentralized wastewater treatment systems.
\end{abstract}

Keywords: Constructed Wetlands (CWs); decentralised wastewater treatment; filter; media; Sol-Gel coating; phosphorus (P); sorption; adsorption isotherm experiments; Langmuir; Freundlich

\section{Introduction}

Phosphorus $(\mathrm{P})$ is a limited and non-renewable resource, while at the same time being an essential plant nutrient, with $\mathrm{P}$ deficiency negatively affecting plant growth and production [1,2]. P fertilization of agricultural fields is therefore crucial to secure a sustainable food production, and the demand will further increase with the growing world population $[3,4]$. The majority of $\mathrm{P}$ fertilizers are obtained from phosphate rock reserves, but these reserves have been estimated to become depleted in the future $[5,6]$. Reserve estimations have been heavily debated depending on the assumptions made and the parameters included in the models, e.g., if the reserves are finite or if the reserves depend on price-driven changes, the future $\mathrm{P}$ management, supply-demand dynamics, etc. [3,7]. Nevertheless, these reserves have been estimated to become depleted in the 22nd-23rd century at current extraction rates [5,6]. It is therefore imperative to recover and reuse $\mathrm{P}$ from some of the important waste streams in the society, and to recycle P into agricultural production. 
One important unexploited stream is wastewater. Several P reclamation strategies exist, with one being $\mathrm{P}$ sorption, which is the combined process of adsorption to the surface of the material and absorption into the material interior. This process is especially important in nature-based solutions, such as Constructed Wetlands (CWs). In CWs the $P$ removal strategies are limited to four main strategies: sorption, chemical precipitation, sedimentation, and uptake by vegetation and algae with subsequent harvest $[8,9]$. These $\mathrm{CW}$ systems have proven to be efficient in Nitrogen $(\mathrm{N})$ removal, but $\mathrm{P}$ has proven elusive, and the P removal capacity strongly depends on the sorption characteristics of the substrate used in the main bed [9-11]. Selection of the bed material is therefore important for the $P$ removal in CWs. However, materials with $P$ removal capacity can also be installed as an external filter outside the main $\mathrm{CW}$ bed, making the exchange of material easier when saturation is achieved [12]. The sorption process constitutes a relatively simple and passive method to overcome P removal limitations in these systems, as when it is installed the material will bind $\mathrm{P}$ without much interference when compared to chemical dosing for $\mathrm{P}$ removal by precipitation or by harvest of plant biomass. The P saturated material could ideally be used directly as soil amendment and for slow release of P $[13,14]$.

Selecting materials with a high $\mathrm{P}$ removal capacity is hence important, and a common method describing the P sorption capacity is by performing batch sorption experiments and fitting adsorption models, e.g., the Langmuir and Freundlich equations. Previous experiments have found that the sorption capacity particularly depends on the calcium (Ca) content $[10,15]$. However, iron (Fe) and the physical characteristics of the materials, e.g., particle size distribution, hydraulic conductivity, physical stability, are also important when selecting a suitable material [16]. Nevertheless, some calcareous materials that have been promising based on their high P sorption capacity, have not had sufficient physical stability. These materials faced operational problems, as they were observed to disintegrate and go into solution during prolonged operation $[17,18]$. Coating the materials could be a means to improve their structural stability for long-term operation, to reduce disintegration of the material, the potential loss of hydraulic performance, etc. As an example, capsules composed of alginate, goethite, and hydrogel were composed and both the mechanical stability and $\mathrm{P}$ adsorption capacity improved when compared to the non-encapsulated goethite [19]. The Sol-Gel coating technology seems ideal for providing new properties to porous and hydraulically unstable materials, and has proven to have a wide range of applications and to provide a simple and cost-efficient approach to functionalize different substrates and materials [20]. Sol-Gel coating provides several advantages, e.g., high mechanical stability, good adhesion to many substrates, controllable porosity, and biological inertness [21]. The intramolecular 3D-cross-linking of the Sol-Gel coating network can be fine-tuned for a given substrate and application, hence allowing penetration of, for example, $\mathrm{P}$, into a porous material and at the same time, strengthen the structural integrity of the material. Performing Sol-Gel coatings for materials with a high P removal potential and facing mechanical stability issues seems ideal to overcome limitations.

The aim of this study was to determine the P sorption capacity of different granular calcareous materials and to assess how Sol-Gel coating of the materials affect their P sorption capacity. Hence, (i) five readily available and low-cost granular calcareous materials were selected and their $\mathrm{P}$ adsorption capacities were assessed by performing isotherm batch experiments, (ii) the most promising of the materials were coated by a Sol-Gel coating technology for increased structural stability of the material, and (iii) the effects of different coatings on the $\mathrm{P}$ adsorption capacity were assessed by performing further isotherm experiments.

\section{Materials and Methods}

\subsection{Non-Coated Materials}

Five calcareous granular materials were selected based on their high Ca content, as previous research has shown that the Ca content is particularly important for the $\mathrm{P}$ removal capacity [10]. Two of the materials have been developed specifically for $\mathrm{P}$ 
removal (Calcite (CAL), IMERYS Industrial Minerals, DK, and Phosclean (PHO), NUWEN ${ }^{\circledR}$, FR), two are commercially available as cat litter $\left(\mathrm{CATSAN}^{\circledR}(\mathrm{CAT}), \mathrm{UK}\right.$, and Hygiene (HYG), MULTIFIT $\left.{ }^{\circledR}, \mathrm{DE}\right)$, and Opoka (OPO, gravelpit in Bełchatów, PL) is a silica-calcite sedimentary rock that has shown promise as a material for P removal. Sand ((SAN), Franzefoss a/s, DK) was included as a low Ca content reference material (Table 1).

Table 1. Information for the six non-coated materials included in the screening experiment.

\begin{tabular}{|c|c|c|c|}
\hline Abbreviation & Material & General Description & $\begin{array}{c}\text { Company or Location, } \\
\text { Country }\end{array}$ \\
\hline CAT & Catsan & $\begin{array}{l}\text { Commercial cat litter product. Calcium silicate gravel } \\
\text { composed of natural chalk and fine quality quartz sand. }\end{array}$ & CATSAN $^{\circledR}, \mathrm{UK}$ \\
\hline CAL & Calcite & Developed for P removal. Calcium carbonate granulates. & $\begin{array}{l}\text { IMERYS Industrial Minerals, } \\
\text { DK (former Damolin) }\end{array}$ \\
\hline HYG & Hygiene & $\begin{array}{l}\text { Commercial cat litter product. Calcium silicate gravel } \\
\text { composed of natural chalk and fine quality quartz sand. }\end{array}$ & MULTIFIT $^{\circledR}, \mathrm{DE}$ \\
\hline $\mathrm{OPO}$ & Opoka & $\begin{array}{c}\text { Natural product. Carbonate silicate gravel produced from } \\
\text { natural reserves. }\end{array}$ & Bełchatów, PL \\
\hline $\mathrm{PHO}$ & Phosclean & $\begin{array}{l}\text { Developed for P removal. Apatite granulates produced } \\
\text { from a Moroccan natural product. }\end{array}$ & $\mathrm{NUWEN}^{\circledR}, \mathrm{FR}$ \\
\hline SAN & Quartz sand & Natural sand extracted from a gravel pit in Denmark. & Franzefoss a/s, DK \\
\hline
\end{tabular}

\subsection{Coated Materials and Coating Procedure}

The coatings of the material with the highest $\mathrm{P}$ adsorption capacity (which turned out to be CAT; see Section 3) were conducted at the Danish Technological Institute (DTI) by the Coating and Polymer Technology Group. An inorganic silica-based hydrosol coating was used. Different coating dilutions and exposure times with an inorganic Sol-Gel base coating were tested (Table 2). The synthesised base coating was diluted with demineralized water to achieve three coating solutions with dilution ratios of 1:10, 1:5 and 1:1 (denoted A, $\mathrm{B}$ and $\mathrm{C}$, respectively). Subsequently, batches of the CAT material were exposed to one of the coating solutions for 5, 10 and $15 \mathrm{~min}$ (denoted I, II and III, respectively). The coatings were carried out at room temperature by soaking raw CAT material in a beaker containing the coating solution (500 g material to $1 \mathrm{~L}$ coating solution). Halfway into the soaking period, the CAT material was carefully stirred with a spatula until no air bubbles from the material were observed. After 5, 10, or $15 \mathrm{~min}$, the excess coating solution was drained from the material by filtration. The coated material was then cured in an oven $\left(140{ }^{\circ} \mathrm{C}\right.$ for $\left.1 \mathrm{~h}\right)$, which provided the final product. The different dilution ratios of the coating solution and exposure periods were expected to provide distinct coating thicknesses and porosities of the coated materials. Consequently, the different coating regimes targeted the optimization of the mechanical and physical stability of the CAT material and the P ad-/absorption in the material.

Table 2. The seven Sol-Gel coated materials produced from the Catsan (CAT) material, and their different coating dilution ratios (A, B and C) and exposure periods (I, II and II).

\begin{tabular}{ccccc}
\hline Abbreviation & Coating Solution (Dilution Ratio) & \multicolumn{2}{c}{ Exposure Period (Minutes) } \\
\hline A-I & \multirow{2}{*}{$1: 10$} & I & 5 \\
A-II & A & II & 10 \\
A-III & & III & 15 \\
\hline B-I & \multirow{2}{*}{ B } & I & II & 5 \\
B-II & \multirow{2}{*}{$1: 1$} & I & 10 \\
\hline C-I & \multirow{2}{*}{ C } & II & 10 \\
C-II & & & \\
\hline
\end{tabular}




\subsection{Physical and Chemical Characterization}

Particle size distribution, bulk porosity, and specific weight were analysed for the non-coated materials. The particle size distributions of the materials on a weight basis $(n=2)$ were analysed using dry-sieving techniques [22]. Distribution plots were used to estimate $d_{10}$ and $d_{60}(\mathrm{~mm})$, i.e., the mess diameter allowing 10 and $60 \%$ of the material to pass through, respectively, from which the uniformity coefficient $\left(U C=d_{60} / d_{10}\right)$ was calculated. The bulk porosity (\%) was determined from the amount of water needed to saturate a known volume of dry material $(n=3)$, and the specific weight $\left(\mathrm{g} \mathrm{mL}^{-1}\right)$ was determined by the ratio between the dry mass and the known volume $(n=3)$.

The concentrations of $\mathrm{Ca}, \mathrm{P}, \mathrm{Fe}$, magnesium $(\mathrm{Mg})$, and aluminium $(\mathrm{Al})$ were analysed for all materials by inductively coupled plasma spectrometry in an Optima 2000 DV ICP-OES (Perkin Elmer Instruments Inc., Shelton, CT, USA) after acid destruction. Representative material subsamples $(n=3)$ were dried $\left(60^{\circ} \mathrm{C}\right.$ for 2 days) and manually milled, followed by destruction of $0.1 \mathrm{~g}$ material in $4 \mathrm{~mL}$ nitric acid $\left(65 \% \mathrm{HNO}_{3}\right)$ and $2 \mathrm{~mL}$ hydrogen peroxide $\left(30 \% \mathrm{H}_{2} \mathrm{O}_{2}\right)$ in a Multiwave 3000 microwave digestion system (Anton Paar, Graz, A). Blanks were included in all destructions and a certified reference material (tomato leaves) was included for quality control.

\subsection{Sorption Isotherm Experiments}

Isotherm experiments were performed as batch experiment in the laboratory for all 13 materials. Approximately $5 \mathrm{~g}$ of material was weighed in $125 \mathrm{~mL}$ acid-washed polyethylene bottles $(n=3)$ and $100 \mathrm{~mL}$ of tap water spiked with $\mathrm{KH}_{2} \mathrm{PO}_{4}$, to give one of nine levels of $\mathrm{P}\left(0,2.5,5,10,20,40,80,160\right.$, and $\left.320 \mathrm{mg} \mathrm{P} \mathrm{L}^{-1}\right)$, were added. For some materials it was necessary to use higher $P$ concentrations $\left(450,640,960\right.$, and $1280 \mathrm{mg} \mathrm{P} \mathrm{L}^{-1}$ ) and/or less material $(1 \mathrm{~g})$ to obtain a stable $\mathrm{P}$ removal at an increased equilibrium $\mathrm{P}$ concentration. Tap water was used to mimic the mineral composition of wastewater. Bottles were sealed with screw top lids and were gently shaken on a reciprocal shaker (100 rpm) at $20^{\circ} \mathrm{C}$ for $24 \mathrm{~h}$. After the $24 \mathrm{~h}$ and settling, the $\mathrm{pH}$ value and conductivity of the solution were measured directly in solution in the bottles. The equilibrium $\mathrm{pH}$ and conductivity were measured for the $\mathrm{P}$ level of $0 \mathrm{mg} \mathrm{P} \mathrm{L}^{-1}$ (only material and tap water). An aliquot of the solution was filtered (5-8 $\mu \mathrm{m}$, Qualitative Filter Paper, Frisenette, Knebel, Denmark) and, after an adequate dilution, was then analysed for P using the Molybdenum Blue Method [23] in an UV-1800 Shimadzu spectrophotometer (Shimadzu Schweiz GmbH, Reinach, Switzerland). Blanks (bottles only with the designated P levels added) were included in every trial as controls.

The $P$ removal from the solution by the materials was calculated from the decrease in solution $\mathrm{P}$ concentration and then was related to the material dry weight, expressed as removed $\mathrm{P}\left(q ; \mathrm{mg} \mathrm{P} \mathrm{g}^{-1}\right.$ dry weight $\left.(\mathrm{DW})\right)$. The equilibrium $\mathrm{P}$ concentration $\left(\mathrm{C}_{e q}\right)$ was calculated for each replica as the remaining P concentration in the solution after $24 \mathrm{~h}$.

\subsection{Adsorption Models}

The P removal $(q)$ and equilibrium P concentration $\left(C_{e q}\right)$ from the sorption isotherm experiments were fitted to two non-linear adsorption models, which allowed for the calculation of the maximum $P$ adsorption capacity $\left(Q_{\max }\right)$ using the Langmuir model and the adsorption constant $(K)$ using the Freundlich model.

The Langmuir adsorption-isotherm equation. The maximum adsorption capacity $\left(Q_{\max } ; \mathrm{mg} \mathrm{P} \mathrm{g}^{-1} \mathrm{DW}\right)$ was estimated using the Langmuir equation, written as:

$$
q=\frac{Q_{\max } \times a \times C_{e q}}{1+a \times C_{e q}}
$$

where $C_{e q}$ is the $\mathrm{P}$ concentration at equilibrium $\left(\mathrm{mg} \mathrm{L}^{-1}\right), q$ is the mass of $\mathrm{P}$ sorbed to the material (mg P g $\left.{ }^{-1} \mathrm{DW}\right)$ and $a$ is a constant related to the materials affinity to adsorb $\mathrm{P}$ $\left(\mathrm{mg}^{-1}\right)$. 
The Freundlich adsorption-isotherm equation. The adsorption constant $\left(K ; \mathrm{mg} \mathrm{P} \mathrm{g}^{-1}\right.$ DW) and the adsorption intensity ( $n$; unit less) were estimated using the Freundlich model, which can be written as:

$$
q=K \times C_{e q}^{n}
$$

where $C_{e q}$ and $q$ are the same as mentioned above and $K$ and $n$ are constants indicating the adsorption capacity and the intensity of the adsorption, respectively.

\subsection{Statistical Analysis}

Principal Component Analysis (PCA) and rotated PCA (rPCA) for selected parameters (conductivity, $\mathrm{pH}$, bulk porosity, $d_{10}, d_{60}$ and concentration of $\mathrm{Al}, \mathrm{P}, \mathrm{Fe}, \mathrm{Ca}$ and $\mathrm{Mg}$ ) were carried out using JMP 14 (SAS Institute). Specific weight and UC were not included in the PCA as they are represented in other parameters. The rotated PCA was performed as a varimax rotation factor analysis to simplify the number of explaining Principal Components (PCs), by only including PCs with eigenvalues $\geq 1$. Fitting of adsorption models to the isotherm data was conducted using the dynamic fit wizard equation for the Langmuir model and the two-parameter power equation for the Freundlich model in SigmaPlot 12.5 (Systat Software Inc., San Jose, CA, USA). All graphs were prepared in SigmaPlot 12.5.

\section{Results}

\subsection{Physical and Chemical Characteristics}

The non-coated materials had different porosities and specific weights (Table 3). HYG and CAT had high porosities ( $>55 \%)$, SAN had a low bulk porosity $(19 \%)$ and the remaining materials had porosities in between (32-40\%). As expected, based on the bulk porosity, the opposite was the case for the specific weight, as SAN had the highest specific weight of $1.59 \mathrm{~g} \mathrm{~mL}^{-1}$ and HYG had the lowest specific weight of $0.35 \mathrm{~g} \mathrm{~mL}^{-1}$. Only minor variations in the particle size distribution of the materials were observed (Table 3 ). The effective size $\left(d_{10}\right)$ ranged from 0.21 to $0.68 \mathrm{~mm}$ and the uniformity coefficient indicated that all materials had a uniform particle size distribution, with UC values of less than three.

Table 3. Physical characteristics of the six non-coated materials. Bulk porosity, specific weight, mess diameter allowing $10 \%$ and $60 \%$ of the material to pass through and uniformity coefficient $(n=2$ for particle analysis, $n=3$ for bulk porosity and specific weight).

\begin{tabular}{cccccc}
\hline \multirow{2}{*}{ Material } & $\begin{array}{c}\text { Bulk } \\
\text { Porosity }\end{array}$ & $\begin{array}{c}\text { Specific } \\
\text { Weight }\end{array}$ & $\boldsymbol{d}_{\mathbf{1 0}}$ & $\boldsymbol{d}_{\mathbf{6 0}}$ & $\mathrm{UC}$ \\
\cline { 2 - 6 } & $\mathbf{( \% )}$ & $\mathbf{( \mathbf { g ~ m L } ^ { - 1 } )}$ & $\mathbf{( m m )}$ & $\mathbf{( m m )}$ & $\begin{array}{c}\left(\boldsymbol{d}_{\mathbf{6 0}} / \boldsymbol{d}_{\mathbf{1 0}} ;\right. \\
\text { Unitless }\end{array}$ \\
\hline CAT & 56 & 0.47 & 0.55 & 1.20 & 2.18 \\
CAL & 40 & 0.82 & 0.59 & 1.25 & 2.12 \\
HYG & 67 & 0.35 & 0.53 & 1.25 & 2.38 \\
OPO & 32 & 0.95 & 0.61 & 1.30 & 2.15 \\
PHO & 32 & 1.10 & 0.68 & 1.35 & 1.99 \\
SAN & 19 & 1.59 & 0.21 & 0.60 & 2.86 \\
\hline
\end{tabular}

The equilibrium $\mathrm{pH}$ of the materials varied between 7.8 and 10.9 (Table 4). The coated CAT materials had a higher $\mathrm{pH}$ when compared to the non-coated CAT material. The conductivity of the materials differed significantly, as the equilibrium conductivity ranged between 0.51 and $4.24 \mathrm{mS} \mathrm{cm}^{-1}$. The non-coated CAT material had a high equilibrium conductivity $\left(4.24 \mathrm{mS} \mathrm{cm}^{-1}\right)$ and the conductivities decreased when coated $\left(2.88-4.23 \mathrm{mS} \mathrm{cm}^{-1}\right)$. 
Table 4. Chemical characteristics for non-coated and coated materials. Equilibrium (EQ) $\mathrm{pH}$ and conductivity, and the mineral concentration of $\mathrm{Al}, \mathrm{P}, \mathrm{Fe}, \mathrm{Ca}$, and $\mathrm{Mg}$. Values are means of triplicates $(n=3)$.

\begin{tabular}{|c|c|c|c|c|c|c|c|c|}
\hline & & 50 & EQ Conductivity & $\mathrm{Ca}$ & $\mathbf{P}$ & Mg & Al & $\mathrm{Fe}$ \\
\hline & VIaterial & $\mathbf{L}$ & $\left(\mathrm{mS} \mathrm{cm}^{-1}\right)^{a}$ & $\left(\mathrm{mg} \mathrm{g}^{-1} \mathrm{DW}\right)$ & $\left(\mathrm{mg} \mathrm{g}^{-1} \mathrm{DW}\right)$ & $\left(\mathrm{mg} \mathrm{g}^{-1} \mathrm{DW}\right)$ & $\left(\mathrm{mg} \mathrm{g}^{-1} \mathrm{DW}\right)$ & $\left(\mathrm{mg} \mathrm{g}^{-1} \mathrm{DW}\right)$ \\
\hline \multirow{6}{*}{ 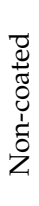 } & CAT & 9.2 & 4.24 & 179 & 0.13 & 16.8 & 0.9 & 0.6 \\
\hline & CAL & 8.8 & 2.93 & 294 & 0.30 & 5.5 & 4.2 & 1.6 \\
\hline & HYG & 9.9 & 1.28 & 225 & 0.26 & 4.5 & 10.8 & 5.6 \\
\hline & $\mathrm{OPO}$ & 8.6 & 0.39 & 133 & 0.27 & 3.2 & 16.9 & 10.5 \\
\hline & $\mathrm{PHO}$ & 7.8 & 1.04 & 333 & 115.82 & 4.7 & 8.6 & 2.0 \\
\hline & SAN & 8.1 & 0.51 & 9 & 0.16 & 0.7 & 2.3 & 5.5 \\
\hline \multirow{7}{*}{ 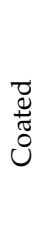 } & A-I & 9.7 & 3.18 & 174 & 0.10 & 12.4 & 1.3 & 0.7 \\
\hline & A-II & 9.3 & 3.14 & 160 & 0.07 & 13.4 & 1.2 & 0.6 \\
\hline & A-III & 10.1 & 2.88 & 182 & 0.11 & 12.3 & 1.4 & 0.9 \\
\hline & B-I & 10.6 & 3.57 & 157 & 0.07 & 12.8 & 1.2 & 0.6 \\
\hline & B-II & 9.8 & 3.30 & 153 & 0.06 & 10.7 & 1.2 & 0.6 \\
\hline & C-I & 10.9 & 3.87 & 146 & 0.08 & 9.9 & 1.2 & 0.6 \\
\hline & C-II & 10.8 & 4.23 & 146 & 0.05 & 8.8 & 1.2 & 0.6 \\
\hline
\end{tabular}

a Tap water had a $\mathrm{pH}$ of 8.5 and a conductivity of $0.500 \mathrm{mS} \mathrm{cm}^{-1}$.

The mineral composition of the materials varied greatly (Table 4). All materials, except SAN, had high concentrations of $\mathrm{Ca}\left(133-333 \mathrm{mg} \mathrm{Ca} \mathrm{g}^{-1} \mathrm{DW}\right)$, with PHO and CAL having concentrations $>250 \mathrm{mg} \mathrm{Ca} \mathrm{g}^{-1} \mathrm{DW}$. The Ca concentrations in the coated CAT materials (146-182 $\mathrm{mg} \mathrm{Ca} \mathrm{g}^{-1} \mathrm{DW}$ ) were, as expected, at the same level as the Ca concentration of the non-coated CAT material. The PHO material had a very high P concentration of $115.82 \mathrm{mg} \mathrm{P} \mathrm{g}^{-1} \mathrm{DW}$, while all the remaining materials had low $\mathrm{P}$ concentrations ( $\left.<0.33 \mathrm{mg} \mathrm{P} \mathrm{g}^{-1} \mathrm{DW}\right)$. The $\mathrm{Mg}$ concentrations in the non-coated materials varied significantly (0.7-16.8 $\left.\mathrm{mg} \mathrm{Mg} \mathrm{g}^{-1} \mathrm{DW}\right)$ with the CAT material having the highest $\mathrm{Mg}$ concentration. The $\mathrm{Mg}$ concentrations in the coated CAT materials were in the range of 8.8 to $13.4 \mathrm{mg} \mathrm{Mg} \mathrm{g}^{-1} \mathrm{DW}$, and were slightly lower than in the non-coated CAT material. CAL, HYG, OPO, and PHO contained some Fe and Al, and at higher levels than those measured in the CAT material, where concentrations were low in both the non-coated and coated materials.

\subsection{Phosphorus Removal Isotherms}

Plotting the removed $\mathrm{P}$ as a function of the equilibrium $\mathrm{P}$ concentration revealed that the non-coated materials behaved differently (Figure 1). Differences in the average $P$ removal $(n=3)$ were most apparent at high initial P concentrations, with the removed $\mathrm{P}(q)$ ranging from 0.3 to $39.5 \mathrm{mg} \mathrm{P} \mathrm{g}^{-1}$ DW. Particularly, the CAT, CAL, and HYG materials had higher $\mathrm{P}$ removals when compared to OPO, PHO, and SAN. Based on visual inspection of the $\mathrm{P}$ removal isotherms, the CAT was the most promising material, i.e., the material showing the highest $P$ removal (Figure 1). 


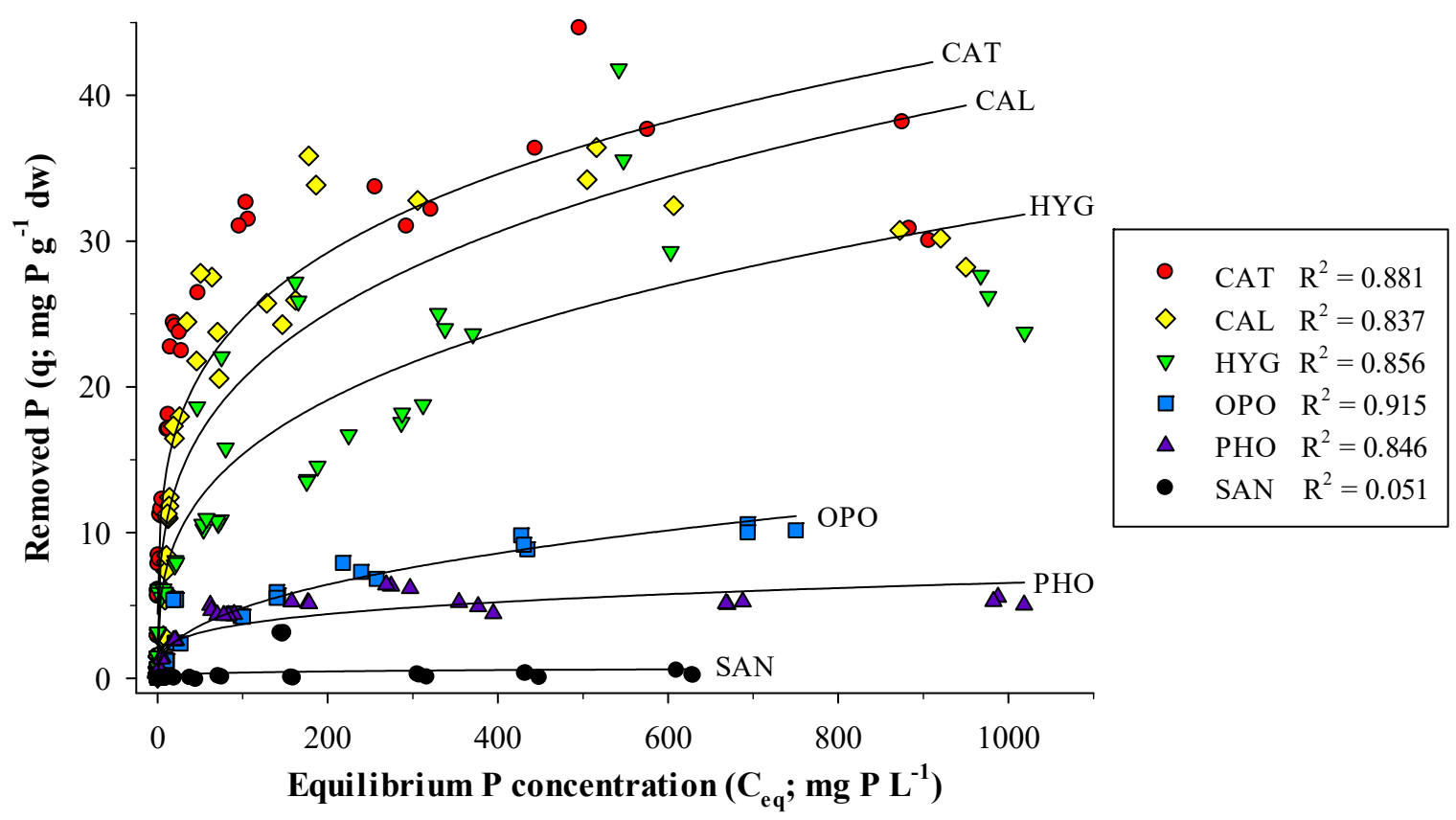

(a)

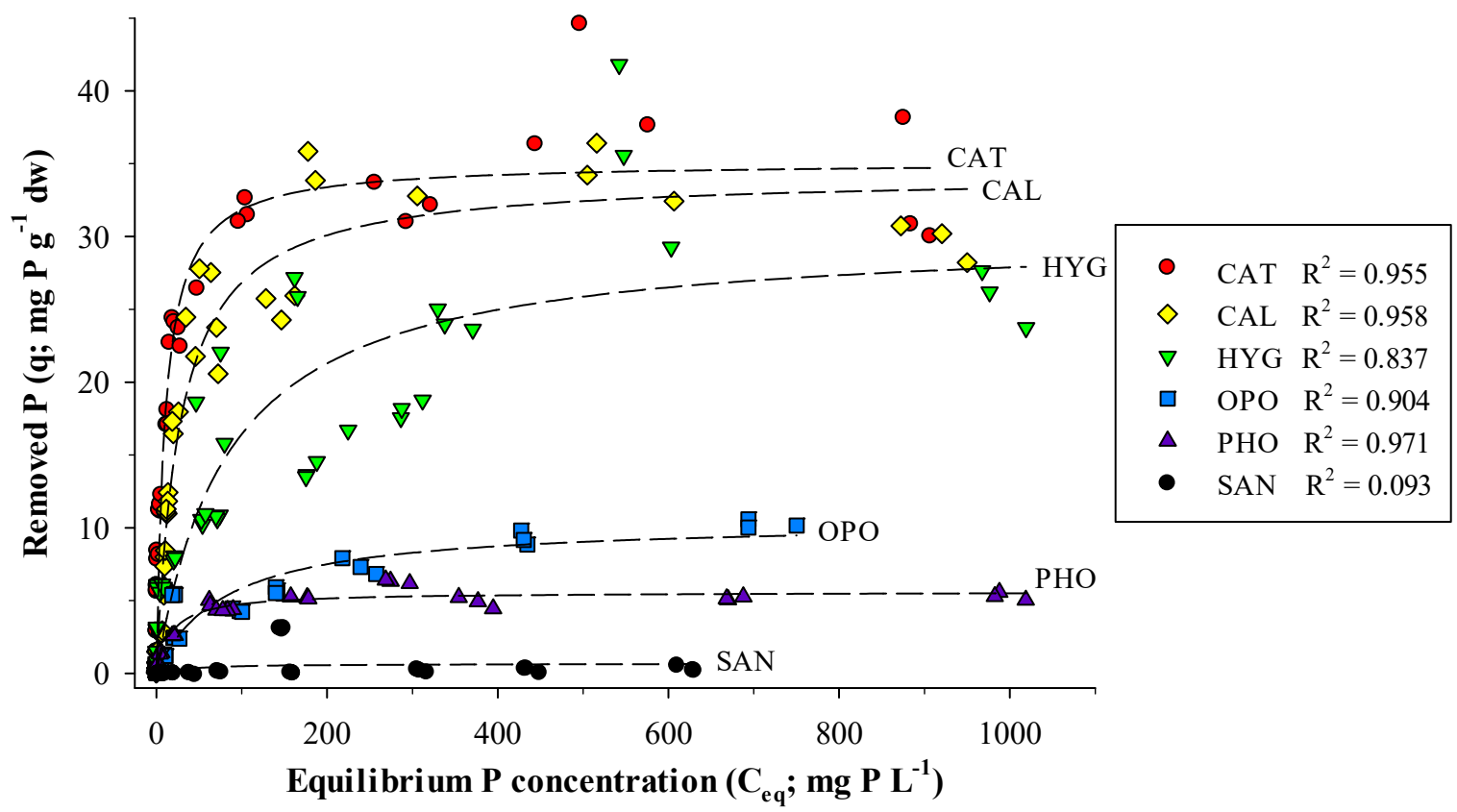

(b)

Figure 1. Phosphorus $(\mathrm{P})$ removal isotherms for the non-coated materials, plotting the removed $\mathrm{P}$ against the equilibrium $\mathrm{P}$ concentration fitted with the (a) Freundlich adsorption model $\left(q=K \times C_{e q}{ }^{n}\right)$ and (b) Langmuir adsorption model $q=\left(Q_{\max } \times \mathbf{a} \times C_{e q}\right) /\left(1+\left(a \times C_{e q}\right)\right)$. The initial P concentrations were in the range of 5 to $640-1280 \mathrm{mg} \mathrm{L}^{-1}$. The Freundlich adsorption parameters (adsorption constant $(K)$ and sorption intensity $(1 / n)$ and the Langmuir adsorption parameters (the maximum $\mathrm{P}$ adsorption capacity $\left(Q_{\max }\right)$ and sorption affinity $(a)$ are reported in Table 5. 
Table 5. Freundlich and Langmuir adsorption parameters for non-coated and coated materials tested using sorption isotherm experiments. Freundlich adsorption parameters $\left(q=K \times C_{e q}{ }^{n}\right)$ with adsorption constant and sorption intensity. Langmuir adsorption parameters $\left(q=\left(Q_{\max } \times a \times C_{e q}\right) /\left(1+\left(a \times C_{e q}\right)\right)\right.$ with the maximum $\mathrm{P}$ adsorption capacity and sorption affinity. The coated materials were produced from CAT material with different dilution ratios of the coating (A, B, and $\mathrm{C})$ and exposure periods (I, II and II).

\begin{tabular}{|c|c|c|c|c|c|c|c|}
\hline & & \multicolumn{3}{|c|}{ Freundlich Adsorption Parameters } & \multicolumn{3}{|c|}{ Langmuir Adsorption Parameters } \\
\hline \multicolumn{2}{|c|}{ Material } & $\begin{array}{c}\text { Adsorption Constant } \\
\left(K \cdot \mathrm{mg}^{-1} \mathrm{~g}^{-1} \mathrm{DW}\right)\end{array}$ & $\begin{array}{c}\text { Intensity }(1 / n \text {; } \\
\text { Unitless) }\end{array}$ & $\mathbf{R}^{2}$ & $\begin{array}{c}\text { Maximum } \\
\text { Adsorption Capacity }\end{array}$ & Affinity $(a$ & $\mathbf{R}^{2}$ \\
\hline \multirow{6}{*}{ 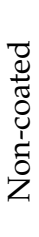 } & CAT & 8.0 & 4.1 & 0.881 & 35.1 & 0.098 & 0.955 \\
\hline & CAL & 5.4 & 3.5 & 0.837 & 34.2 & 0.036 & 0.958 \\
\hline & HYG & 3.6 & 3.2 & 0.856 & 30.2 & 0.012 & 0.837 \\
\hline & $\mathrm{OPO}$ & 0.7 & 2.4 & 0.915 & 10.5 & 0.013 & 0.904 \\
\hline & $\mathrm{PHO}$ & 1.2 & 4.1 & 0.846 & 5.6 & 0.057 & 0.971 \\
\hline & SAN & 0.1 & 3.9 & 0.051 & 0.7 & 0.026 & 0.093 \\
\hline \multirow{7}{*}{$\begin{array}{l}\tilde{D} \\
\tilde{0} \\
\dot{0}\end{array}$} & A-I & 6.6 & 4.7 & 0.869 & 22.1 & 0.843 & 0.889 \\
\hline & A-II & 6.3 & 4.1 & 0.932 & 24.7 & 0.514 & 0.907 \\
\hline & A-III & 6.2 & 4.5 & 0.826 & 21.9 & 0.461 & 0.869 \\
\hline & B-I & 5.2 & 4.0 & 0.890 & 24.2 & 0.050 & 0.854 \\
\hline & B-II & 4.2 & 4.2 & 0.908 & 13.6 & 0.487 & 0.934 \\
\hline & C-I & 2.2 & 3.6 & 0.902 & 9.6 & 0.173 & 0.947 \\
\hline & C-II & 1.4 & 3.1 & 0.959 & 7.8 & 0.137 & 0.839 \\
\hline
\end{tabular}

Bold $\mathrm{R}^{2}$ values indicate significant correlations with $p<0.0001$.

The P removal for the non-coated and coated materials were described using the Freundlich (Equation (2)) and the Langmuir (Equation (1)) models, and the obtained adsorption parameters are listed in Table 5.

Fitting Equation (2) for the non-coated materials resulted in $\mathrm{R}^{2}>0.83$, except for SAN, which had a low coefficient of determination (Figure 1a, Table 5). The adsorption constant ranged from $0.1 \mathrm{mg} \mathrm{P} \mathrm{g}^{-1} \mathrm{DW}$ for SAN to $8.0 \mathrm{mg} \mathrm{P} \mathrm{g}^{-1} \mathrm{DW}$ for CAT, which indicated that the CAT material could achieve the highest $P$ removal capacity. Even though variations in $K$ were observed, only minor variations in the adsorption intensity (2.4-4.1) were evident among materials (Table 5). The stability issues were mainly observed for the materials with the highest $\mathrm{P}$ sorption capacity (CAT, HYG and CAL).

Fitting Equation (1) for the non-coated materials showed fits of $R^{2}>0.83$, except for SAN, which had a low coefficient of determination (Figure 1b, Table 5). CAT, CAL, and HYG had high maximum P adsorption capacities in the range of 30.2 to $35.1 \mathrm{mg} \mathrm{P} \mathrm{g}^{-1} \mathrm{DW}$, with CAT being the most promising material, with the highest $P$ removal potential. CAT also had the highest adsorption affinity of $0.098 \mathrm{~L} \mathrm{mg}^{-1}$ when compared to the remaining non-coated materials (Table 5).

Fitting the models for the coated materials resulted in $R^{2}>0.82$ and $R^{2}>0.84$ for the Freundlich and Langmuir model, respectively (Table 5). The adsorption constant ranged from $1.4 \mathrm{mg} \mathrm{P} \mathrm{g}^{-1} \mathrm{DW}$ for $\mathrm{C}-\mathrm{II}$ to $6.6 \mathrm{mg} \mathrm{P} \mathrm{g}^{-1} \mathrm{DW}$ for A-I, and the maximum adsorption capacity ranged from $7.8 \mathrm{mg} \mathrm{P} \mathrm{g}^{-1} \mathrm{DW}$ for C-II to $24.7 \mathrm{mg} \mathrm{P} \mathrm{g}^{-1} \mathrm{DW}$ for A-II (Table 5). Coating the CAT material decreased the P binding capacity of the CAT material, as the non-coated CAT material had higher $K$ and $Q_{\max }$ values when compared to all coated CAT materials (Figure 2, Table 5). 


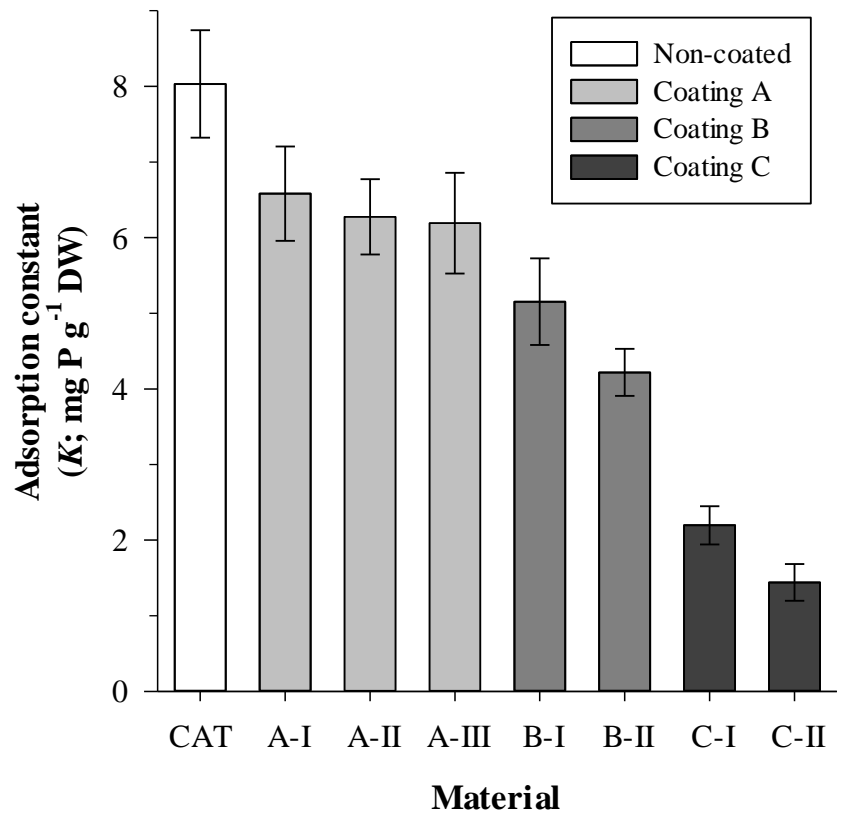

(a)

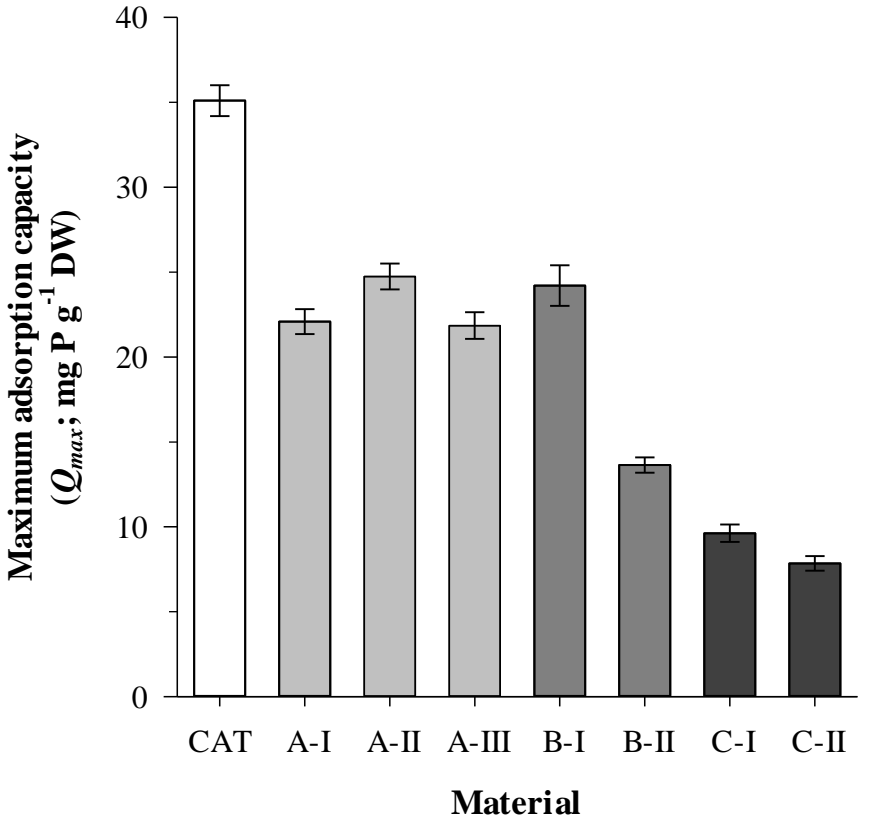

(b)

Figure 2. Freundlich and Langmuir adsorption parameters for non-coated and coated CAT materials. (a) Freundlich adsorption constant and (b) Langmuir maximum adsorption capacity. The coated materials were produced from CAT materials with different dilution ratios of the coating (A, B and C) and exposure periods (I, II and II). Values are based on the model fitting \pm standard error (SE).

The effects of the three coating dilution ratios (A, B and C) were apparent both for $K$ and $Q_{\max }$, as both parameters decreased when the coating became thicker, i.e., as the ratio of the coating base in the coating dilution increased (moving from coating $\mathrm{A} \rightarrow \mathrm{B} \rightarrow \mathrm{C}$ ) (Figure 2, Table 5). In particular, coating $C$, i.e., the densest coating with the largest proportion of coating base added in the diluted coating solution, resulted in lower values for $K$ and $Q_{\max }$ (Figure 2, Table 5).

The effects of the different exposure periods were evident for $K$ and $Q_{\max }$ in-between materials with coating B and $C$, as both $K$ and $Q_{\max }$ decreased with longer exposure periods (Figure 2, Table 5). There was no difference in $K$ for coating A between exposure period I, II, and III, but differences became apparent for coating B and C, as $K$ decreased with longer exposure periods, i.e., comparing exposure period I and II for coating B and C (Figure 2a, Table 5). Likewise, $Q_{\max }$ decreased for coating $\mathrm{B}$ and $\mathrm{C}$ with longer exposure periods, i.e., comparing exposure period I and II for coating B and C (Figure 2b, Table 5). The effect of the different exposure periods on $Q_{\max }$ for coating A presented a more unclear pattern, as material A-II and B-I had the highest $Q_{\max }$ values of 24.7 and $24.1 \mathrm{mg} \mathrm{P} \mathrm{g}^{-1} \mathrm{DW}$, respectively, followed by the adsorption capacities of A-I and A-III (Figure 2b, Table 5). Generally, the smallest values of $K$ and $Q_{\max }$ were observed for material C-II, i.e., the material with the thickest/densest coating, hence, the less diluted base coating solution with the longest exposure period.

The combined effects of the coating dilutions (A, B, and C) and exposure periods (I, II, and III) affected the $P$ adsorption potential of the materials, as both $K$ and $Q_{\max }$ decreased with a larger proportion of the coating base in the dilution $\left(K\right.$ and $Q_{\max }$ decreased moving from $\mathrm{A} \rightarrow \mathrm{B} \rightarrow \mathrm{C}$ ) and with a longer exposure period ( $K$ and $Q_{\max }$ decreased moving from $\mathrm{I} \rightarrow \mathrm{II} \rightarrow \mathrm{III})$. The thinner coating preserved more of the adsorption potential found in the non-coated CAT material, as both the coating solution and exposure period affected the adsorption parameters. 


\subsection{Important Chemical and Physical Characteristics for the Materials $P$ Adsorption}

A Principal Component Analysis was performed to identify the importance of the chemical and physical characteristics of the non-coated materials for their P adsorption capacities. The first two Principal Components accounted for $70.0 \%$ of the variation, with PC1 and PC2 explaining 40.9 and $29.1 \%$ of the variation, respectively (Table 6). However, it was difficult to separate the different parameters into distinctive groups based on the PCA, as the majority of the parameters appeared several times, with high loadings in the different eigenvectors. Therefore, a Varimax rotated Principal Component Analysis (Varimax rPCA) was performed by extracting the PCs with eigenvalues $\geq 1$. This reduced the number of PCs from the five original ones to three new rotated PC (rPC) factors, which accounted for $91.7 \%$ of variability in the original data (Figure 3, Table 6). The rPCs could be interpreted as (i) a texture- and calcium-related factor (high loadings for $d_{10}, d_{60}$ and Ca content), (ii) a conductivity- and metal-related factor (high loadings for conductivity and $\mathrm{Mg}$ content; negative high loadings for $\mathrm{Al}$ and Fe contents), (iii) a mixed-variable related with bulk porosity, $\mathrm{pH}$ and $\mathrm{P}$ content (high loadings for bulk porosity and $\mathrm{pH}$; negative loading for $\mathrm{P}$ content) (Table 6).

Table 6. Principle Component Analysis (PCA) and Varimax rotated Principal Component Analysis (Varimax rPCA) for the non-coated materials. PCA with eigenvalue, percentage, and cumulative percentage. Varimax rPCA with loadings for the different parameters of the rotated Principal Components (rPC 1, rPC 2, and rPC 3). The analyses were performed on the conductivity, $\mathrm{pH}$, bulk porosity, particle size distribution $\left(d_{10}\right.$ and $\left.d_{60}\right)$, and mineral concentrations of $\mathrm{Al}, \mathrm{P}, \mathrm{Fe}, \mathrm{Ca}$, and Mg. Specific weight and uniformity coefficient have been excluded, as they are represented in other parameters. Proportion of variance (POV).

\begin{tabular}{|c|c|c|c|}
\hline \multicolumn{4}{|c|}{ Principal Component Analysis } \\
\hline Principal Component & Eigenvalue & $\begin{array}{l}\text { Proportion of } \\
\text { Variance (\%) }\end{array}$ & $\begin{array}{c}\text { Cumulative POV } \\
(\%)\end{array}$ \\
\hline PC1 & 4.09 & 40.9 & 40.9 \\
\hline PC2 & 2.91 & 29.1 & 70.0 \\
\hline PC3 & 2.17 & 21.7 & 91.7 \\
\hline PC4 & 0.54 & 5.4 & 97.2 \\
\hline PC5 & 0.29 & 2.9 & 100.0 \\
\hline \multicolumn{4}{|c|}{ Varimax rotated Principal Component Analysis } \\
\hline Parameter & rPC1 & rPC2 & rPC3 \\
\hline Bulk porosity (\%) & 0.363 & -0.241 & 0.830 \\
\hline$d_{10}(\mathrm{~mm})$ & 0.972 & 0.001 & 0.096 \\
\hline$d_{60}(\mathrm{~mm})$ & 0.954 & 0.045 & 0.257 \\
\hline $\mathrm{pH}$ & 0.065 & -0.051 & 0.965 \\
\hline Conductivity $\left(\mathrm{mS} \mathrm{cm}^{-1}\right)$ & 0.153 & -0.861 & 0.415 \\
\hline $\mathrm{P}\left(\mathrm{mg} \mathrm{g}^{-1} \mathrm{DW}\right)$ & 0.593 & -0.074 & -0.715 \\
\hline $\mathrm{Ca}\left(\mathrm{mg} \mathrm{g}^{-1} \mathrm{DW}\right)$ & 0.907 & -0.261 & -0.063 \\
\hline $\mathrm{Mg}\left(\mathrm{mg} \mathrm{g}^{-1} \mathrm{DW}\right)$ & 0.225 & -0.735 & 0.441 \\
\hline $\mathrm{Al}\left(\mathrm{mg} \mathrm{g}^{-1} \mathrm{DW}\right)$ & 0.435 & 0.884 & 0.117 \\
\hline $\mathrm{Fe}\left(\mathrm{mg} \mathrm{g}^{-1} \mathrm{DW}\right)$ & -0.211 & 0.945 & 0.129 \\
\hline
\end{tabular}

Boldface type indicate variables with high loading. 


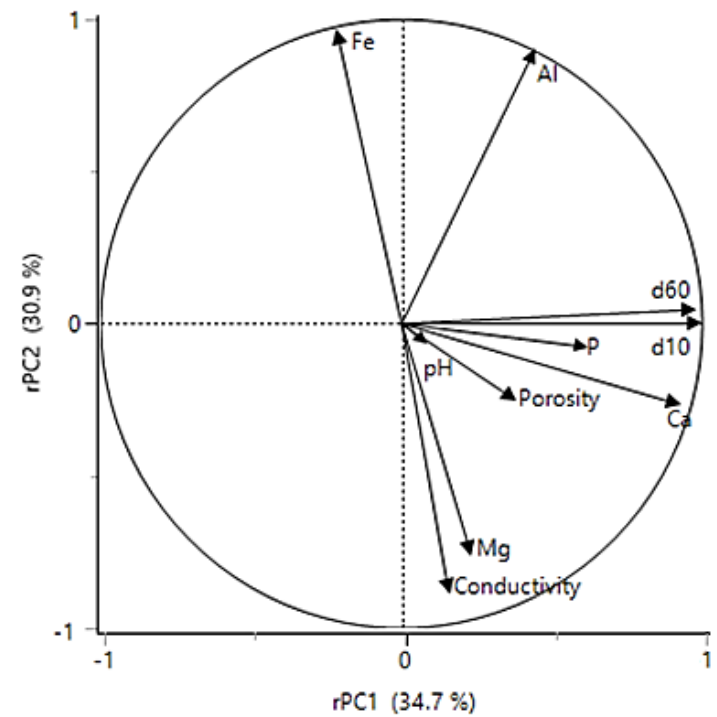

Figure 3. Varimax rotated Principal Component Analysis (Varimax rPCA) plot with rPC1 (34.7\%) and rPC2 (30.9\%) performed for the following parameters of the non-coated materials: conductivity, $\mathrm{pH}$, bulk porosity, particle size distribution $\left(d_{10}\right.$ and $\left.d_{60}\right)$, and mineral concentration of $\mathrm{Al}, \mathrm{P}, \mathrm{Fe}, \mathrm{Ca}$, and $\mathrm{Mg}$.

\section{Discussion}

The aim of this study was to evaluate different calcareous granular materials for use as $\mathrm{P}$ binding filters in wastewater treatment systems, and to what extent Sol-Gel coating affects their $\mathrm{P}$ binding capacity. We identified several promising calcareous materials. The commercial cat litter Catsan was the most promising material with the highest $\mathrm{P}$ sorption capacity, but the industrially developed Calcite material and the commercial cat litter Hygiene were also promising, with just slightly lower P sorption capacities.

Catsan, Calcite, and Hygiene were superior for removing $\mathrm{P}$ when compared to the other tested materials and had maximum $\mathrm{P}$ adsorption capacities of $30-35 \mathrm{~g} \mathrm{P} \mathrm{kg}^{-1}$. Likewise, the three materials had $\mathrm{P}$ adsorption capacities that are several folds higher than values reported for gravel, soils, and different sands (Table 7). Additionally, the studied materials outperformed the $\mathrm{P}$ adsorption capacities reported for Apatite, Calcite, and marble (Table 7). Generally, Catsan, Calcite, and Hygiene had from three times as high to four orders of magnitude higher capacities when compared to other natural materials. However, when comparing the three studied materials to other materials categorised as man-made or industrial by-products, it resulted in a more mixed picture. Catsan, Calcite, and Hygiene had higher P sorption capacities than reported for light expanded clay aggregates (LECA) and recycled concrete; however, heated Opoka and hydrated metal oxides outperformed the studied materials with higher P sorption capacities (Table 7).

Table 7. Reported P adsorption capacities in literature.

\begin{tabular}{ccc}
\hline Material & P Adsorption Capacity $\left(\mathbf{g} \mathbf{~ P ~} \mathbf{~ g}^{-\mathbf{1}}\right)$ & Reference \\
\hline Gravel & $0.03-0.49$ & {$[11,24]$} \\
Soil & $0.001-1.396$ & {$[11,25-27]$} \\
Sand & $0.02-9.60$ & {$[11,27-32]$} \\
\hline Apatite & $0.3-7.9$ & {$[15,33,34]$} \\
Marble & 0.98 & {$[35]$} \\
Calcite & $0.7-7.5$ & {$[33,36,37]$} \\
\hline LECA & $0.42-1.00$ & {$[36,38]$} \\
Recycled concrete & $0.3-6.9$ & {$[33,39]$} \\
Heated Opoka & 120 & {$[40]$} \\
Hydrated metal oxides & $74-111$ & {$[41]$} \\
\hline
\end{tabular}


The texture and the Ca content of the materials were the most important physical and chemical characteristics determining their $\mathrm{P}$ adsorption capacities. This is in agreement with previous findings for 13 Danish natural sands [28,38] and the findings of a literature review based on 22 scientific papers, including studies of natural materials, industrial byproducts, and man-made products [13]. However, other studies report different findings. Leader et al. [26] did find a relation between material texture and P sorption for sands, but no relation for other materials studied. Additionally, Mann and Bavor [23] did not find any relation between any physical and chemical characteristics of gravel and blast furnace slag and their P sorption capacity. Concludingly, there seems to be overwhelming evidence in the literature that the high $\mathrm{P}$ sorption capacities of many materials are related to their high $\mathrm{Ca}$ content. However, this relationship is not straightforward, as materials with a high $\mathrm{Ca}$ content do not always imply a high P sorption capacity. Several studies have reported large variations in $\mathrm{P}$ sorption capacity between materials with similar Ca content, highlighting the interactions with other characteristics of the materials $[13,36]$.

Another question is if the physical stability of the materials can be improved without compromising the materials' P removal capacities, e.g., by Sol-Gel coating technology, which has the advantage of providing high mechanical stability [21]. Ideally, the coating should improve the physical stability of the material while still retaining the P removal ability. The effect of the coating on the sorption capacity was evident, as we observed a trade-off between retaining the P sorption capacity and the thickness of the coating. The lightly coated materials, i.e., materials coated with the most diluted coating solution and experiencing the shortest coating exposure period, preserved more of the sorption capacity found in the non-coated CAT material. It can be concluded that the coating should not be too thick, as this will reduce the $\mathrm{P}$ binding capacity.

The removal capacities of Hygiene, non-coated Catsan, and Calcite were 11, 16, and $28 \mathrm{~kg} \mathrm{P} \mathrm{m}{ }^{-3}$, respectively. Considering that domestic wastewater typically contains $1 \mathrm{~kg} \mathrm{P}$ per Person Equivalents (PE) per year, the needed amount of material would be around 0.09, 0.06 , or $0.04 \mathrm{~m}^{3}$ material $\mathrm{PE}^{-1} \mathrm{yr}^{-1}$, respectively. However, due to problems with the physical stability of the materials, introducing the Sol-Gel coating was necessary. When coating the materials, some of the P sorption capacity is compromised, as the coated CAT materials performing best had removal capacities of approximately $11-12 \mathrm{~kg} \mathrm{P} \mathrm{m}^{-3}$. Additionally, under the same conditions, the needed amount of material would be around $0.09 \mathrm{~m}^{3} \mathrm{ma}$ terial $\mathrm{PE}^{-1} \mathrm{yr}^{-1}$. At these removal capacities, a single household (5 PE) would need an external filter of $4 \mathrm{~m}^{3}$ if exchanging the material every 10 years. However, the $\mathrm{P}$ sorption capacities measured in batch experiments are not directly transferable to realistic settings in treating wastewater effluents $[10,33]$, and upscaling from batch experiments to column and full-scale systems are needed to fully evaluate the materials' potential. Installing external P filters in line with the wastewater treatment could be one possible solution [38], especially for decentralized wastewater treatment systems, in which P removal has been elusive.

The needed volumes for the materials are of an amount that is of a practical usage if an external filter is considered. Nevertheless, the maximum P sorption capacity is not directly transferrable to $\mathrm{P}$ removal from wastewater treatment under more realistic settings, and the filters most likely will saturate faster due to not-ideal hydraulics. Column experiments and instalment in more realistic settings will provide a more accurate picture of the materials' $\mathrm{P}$ removal capacity.

In conclusion, the development of $\mathrm{P}$ binding materials constitutes a useful technology in decentralized wastewater treatment systems. This may promote a more circular nutrient cycle, hence, linking removal closer to recovery and reuse. The P removal abilities of both the coated and non-coated materials are of a practical use in externally constructed wetland filters. However, caution should be exercised when transferring results from batch experiments into realistic settings. 


\begin{abstract}
Author Contributions: Conceptualization, S.M.J., H.S., F.H.B., H.B. and C.A.A.; Methodology, S.M.J., H.S., F.H.B., H.B. and C.A.A.; Software, S.M.J. and H.B.; Validation, S.M.J., H.S. and F.H.B.; Formal Analysis, S.M.J. and H.B.; Investigation, S.M.J. and H.S., F.H.B.; Resources, C.A.A. and H.B.; Data Curation, S.M.J.; Writing—Original Draft Preparation, S.M.J.; Writing—Review \& Editing, S.M.J., H.S., F.H.B., H.B. and C.A.A.; Visualization, S.M.J.; Supervision, C.A.A. and H.B.; Project Administration, S.M.J. and C.A.A.; Funding Acquisition, C.A.A. and H.B. All authors have read and agreed to the published version of the manuscript.
\end{abstract}

Funding: The study was supported by the INCOVER EU project from the European Union's Horizon 2020 research and innovation program under grant agreement $n^{\circ} 689242$ and INTEXT EU project funded from the European Union's LIFE18 ENV/ES/000233.

Institutional Review Board Statement: Not applicable.

Informed Consent Statement: Not applicable.

Data Availability Statement: The data presented in this study are available on request from the corresponding author. The data are not publicly available due to the ongoing work and planning of further development of the coated calcareous materials.

Acknowledgments: Solvei Mundbjerg Jensen acknowledges a PhD scholarship from the Aarhus University Centre for Water Technology (WATEC) and Sino-Danish Centre for Education and Research (SDC).

Conflicts of Interest: The authors declare no conflict of interest. The funders had no role in the design of the study; in the collection, analyses, or interpretation of data; in the writing of the manuscript, or in the decision to publish the results.

\title{
References
}

1. Usuda, H. Phosphate Deficiency in Maize. V. Mobilization of Nitrogen and Phosphorus within Shoots of Young Plants and Its Relationship to Senescence. Plant Cell Physiol. 1995, 36, 1041-1049. [CrossRef]

2. Jacob, J.; Lawlor, D.W. Stomatal and Mesophyll Limitations of Photosynthesis in Phosphate Deficient Sunflower, Maize and Wheat Plants. J. Exp. Bot. 1991, 42, 1003-1011. [CrossRef]

3. Rittmann, B.E.; Mayer, B.; Westerhoff, P.; Edwards, M. Capturing the Lost Phosphorus. Chemosphere 2011, 84, 846-853. [CrossRef] [PubMed]

4. Kok, D.J.D.; Pande, S.; Van Lier, J.B.; Ortigara, A.R.C.; Savenije, H.; Uhlenbrook, S. Global Phosphorus Recovery from Wastewater for Agricultural Reuse. Hydrol. Earth Syst. Sci. 2018, 22, 5781-5799. [CrossRef]

5. Koppelaar, R.H.E.M.; Weikard, H.P. Assessing Phosphate Rock Depletion and Phosphorus Recycling Options. Glob. Environ. Chang. 2013, 23, 1454-1466. [CrossRef]

6. $\quad$ Edixhoven, J.D.; Gupta, J.; Savenije, H.H.G. Recent Revisions of Phosphate Rock Reserves and Resources: A Critique. Earth Syst. Dyn. 2014, 5, 491-507. [CrossRef]

7. Vaccari, D.A.; Mew, M.; Scholz, R.W.; Wellmer, F.-W. Chapter 2 Exploration: What Reserves and Resources? In Sustainable Phosphorus Management: A Global Transdisciplinary Roadmap; Scholz, R.W., Roy, A.H., Brand, F.S., Hellums, D.T., Ulrich, E.A., Eds.; Springer: Dordrecht, The Netherlands, 2014; pp. 129-151. [CrossRef]

8. $\quad$ Kadlec, R.H.; Knight, R.L. Treatment Wetlands; Lewis Publishers: New York, NY, USA, 1996.

9. Vymazal, J. Removal of Nutrients in Various Types of Constructed Wetlands. Sci. Total Environ. 2007, 380, 48-65. [CrossRef]

10. Arias, C.A.; Brix, H. Phosphorus Removal in Constructed Wetlands: Can Suitable Alternative Media Be Identified? Water Sci. Technol. 2005, 51, 267-273. [CrossRef]

11. Cui, L.; Zhu, X.; Ma, M.; Ouyang, Y.; Dong, M.; Zhu, W.; Luo, S. Phosphorus Sorption Capacities and Physicochemical Properties of Nine Substrate Materials for Constructed Wetland. Arch. Environ. Contam. Toxicol. 2008, 55, 210-217. [CrossRef]

12. Ballantine, D.J.; Tanner, C.C. Substrate and Filter Materials to Enhance Phosphorus Removal in Constructed Wetlands Treating Diffuse Farm Runoff: A Review. N. Z. J. Agric. Res. 2010, 53, 71-95. [CrossRef]

13. Vohla, C.; Kõiv, M.; Bavor, H.J.; Chazarenc, F.; Mander, Ü. Filter Materials for Phosphorus Removal from Wastewater in Treatment Wetlands-A Review. Ecol. Eng. 2011, 37, 70-89. [CrossRef]

14. Jensen, S.M.; Esposito, C.; Konnerup, D.; Brix, H.; Arias, C.A. Phosphorus Recovery from Wastewater: Bioavailability of P Bound to Calcareous Material for Maize (Zea mays L.) Growth. Recycling 2021, 6, 25. [CrossRef]

15. Molle, P.; Liénard, A.; Grasmick, A.; Iwema, A.; Kabbabi, A. Apatite as an Interesting Seed to Remove Phosphorus from Wastewater in Constructed Wetlands. Water Sci. Technol. 2005, 51, 193-203. [CrossRef]

16. Del Bubba, M.; Arias, C.A.; Brix, H. Phosphorus Adsorption Maximum of Sands for Use as Media in Subsurface Flow Constructed Reed Beds as Measured by the Langmuir Isotherm. Water Res. 2003, 37, 3390-3400. [CrossRef] 
17. Brix, H.; Arias, C.A. Experiments with Wastewater Treatment in Areas with Scattered Settlement with Planted Filter Systems "Forsøg Med Rensning Af Spildevand i Det Åbne Land i Beplantede Filteranlæg", The Danish Environmental Protection Agency (Miljøstyrelsen); Økologisk Byfornyelse Og Spildevandsrensning, Nr. 53. 2004. Available online: https://www2.mst.dk/Udgiv/ publikationer/2004/87-7614-468-2/html/default.htm (accessed on 16 December 2021).

18. Arias, C.A.; Brix, H.; Garza, M.F. Alternatives for Phosphorus Removal in Subsurface Flow Constructed Wetlands. In Proceedings of the International Meeting on Phytodepuration, Murcia, Spain, 19-22 July 2005; pp. 73-79.

19. Siwek, H.; Bartkowiak, A.; Włodarczyk, M. Adsorption of Phosphates from Aqueous Solutions on Alginate/Goethite Hydrogel Composite. Water 2019, 11, 633. [CrossRef]

20. Ciriminna, R.; Fidalgo, A.; Pandarus, V.; Béland, F.; Ilharco, L.M.; Pagliaro, M. The Sol-Gel Route to Advanced Silica-Based Materials and Recent Applications. Chem. Rev. 2013, 113, 6592-6620. [CrossRef]

21. Krzak, J.; Szczurek, A.; Babiarczuk, B.; Gasiorek, J.; Borak, B. Chapter 5: Sol-gel surface functionalization regardless of form and type of substrate. In Handbook of Nanomaterials for Manufacturing Applications. A Volume in Micro and Nano Technologies, 1st ed.; Hussain, C.M., Ed.; Elsevier: Amsterdam, The Netherlands, 2020; pp. 111-147, ISBN 9780128213810.

22. Day, P.R. Particle Fractionation and Particle-Size Analysis. In Methods of Soil Analysis; American Society of Agronomy, Inc.: Madison, WI, USA, 1965; pp. 545-567. [CrossRef]

23. Danish Standard. Water Quality-Determination of Phosphorus-Ammonium Molybdate Spectrometric Method; DS/EN 1189; Danish Standards Association: Charlottenlund, Denmark, 1997.

24. Mann, R.A.; Bavor, H.J. Phosphorus Removal in Constructed Wetlands Using Gravel and Industrial Waste Substrata. Water Sci. Technol. 1993, 27, 107-113. [CrossRef]

25. Mahmood-ul-Hassan, M.; Rashid, A.; Akhtar, M.S. Phosphorus Requirement of Corn and Sunflower Grown on Calcareous Soils of Pakistan. Commun. Soil Sci. Plant Anal. 1993, 24, 1529-1541. [CrossRef]

26. Sakadevan, K.; Bavor, H.J. Phosphate Adsorption Characteristics of Soils, Slags and Zeolite to Be Used as Substrates in Constructed Wetland Systems. Water Res. 1998, 32, 393-399. [CrossRef]

27. Leader, J.W.; Dunne, E.J.; Reddy, K.R. Phosphorus Sorbing Materials: Sorption Dynamics and Physicochemical Characteristics. J. Environ. Qual. 2008, 37, 174-181. [CrossRef]

28. Arias, C.A.; Del Bubba, M.; Brix, H. Phosphorus Removal by Sands for Use as Media in Subsurface Flow Constructed Reed Beds. Water Res. 2001, 35, 1159-1168. [CrossRef]

29. Pant, H.K.; Reddy, K.R.; Lemon, E. Phosphorus Retention Capacity of Root Bed Media of Subsurface Flow Constructed Wetlands Ecol. Eng. 2001, 17, 345-355. [CrossRef]

30. Prochaska, C.A.; Zouboulis, A.I. Removal of Phosphates by Pilot Vertical-Flow Constructed Wetlands Using a Mixture of Sand and Dolomite as Substrate. Ecol. Eng. 2006, 26, 293-303. [CrossRef]

31. Søvik, A.K.; Kløve, B. Phosphorus Retention Processes in Shell Sand Filter Systems Treating Municipal Wastewater. Ecol. Eng. 2005, 25, 168-182. [CrossRef]

32. Ádám, K.; Krogstad, T.; Vråle, L.; Søvik, A.K.; Jenssen, P.D. Phosphorus Retention in the Filter Materials Shellsand and Filtralite P®-Batch and Column Experiment with Synthetic P Solution and Secondary Wastewater. Ecol. Eng. 2007, 29, 200-208. [CrossRef]

33. Molle, P.; Liénard, A.; Grasmick, A.; Iwema, A. Phosphorus Retention in Subsurface Constructed Wetlands: Investigations Focused on Calcareous Materials and Their Chemical Reactions. Water Sci. Technol. 2003, 48, 75-83. [CrossRef]

34. Bellier, N.; Chazarenc, F.; Comeau, Y. Phosphorus Removal from Wastewater by Mineral Apatite. Water Res. 2006, 40, $2965-2971$. [CrossRef]

35. Eljamal, O.; Okawauchi, J.; Hiramatsu, K. Removal of Phosphorus from Water Using Marble Dust as Sorbent Material. J. Environ. Prot. 2012, 3, 709-714. [CrossRef]

36. Drizo, A.; Frost, C.A.; Grace, J.; Smith, K.A. Physico-Chemical Screening of Phosphate-Removing Substrates for Use in Constructed Wetland Systems. Water Res. 1999, 33, 3595-3602. [CrossRef]

37. Seo, C.D.; Hwang, H.S.; Kim, H.J.; Cho, J.S.; Lee, H.J.; Delaune, R.D.; Jugsujinda, A.; Lee, S.T.; Seo, J.Y.; Heo, J.S. Evaluation of 2and 3-Stage Combinations of Vertical and Horizontal Flow Constructed Wetlands for Treating Greenhouse Wastewater. Ecol. Eng. 2008, 32, 121-132. [CrossRef]

38. Brix, H.; Arias, C.A.; Del Bubba, M. Media Selection for Sustainable Phosphorus Removal in Subsurface Flow Constructed Wetlands. Water Sci. Technol. 2001, 44, 47-54. [CrossRef] [PubMed]

39. Deng, Y.; Wheatley, A. Mechanisms of Phosphorus Removal by Recycled Crushed Concrete. Int. J. Environ. Res. Public Health 2018, 15, 357. [CrossRef] [PubMed]

40. Brogowski, Z.; Renman, G. Characterization of Opoka as a Basis for Its Use in Wastewater Treatment. Pol. J. Environ. Stud. 2004, 13, 15-20.

41. Acelas, N.Y.; Martin, B.D.; López, D.; Jefferson, B. Selective Removal of Phosphate from Wastewater Using Hydrated Metal Oxides Dispersed within Anionic Exchange Media. Chemosphere 2015, 119, 1353-1360. [CrossRef] 